\author{
Silvana Đurašević \\ University Mediterranean Podgorica, \\ MTS - Montenegro Tourism School, Bar, Montenegro \\ UDC: 005.346:338.48
}

\title{
THEMATIC TOURISM AS AN IMPORTANT SEGMENT IN THE BUSINESS OF MODERN TOUR OPERATORS
}

\begin{abstract}
The aim of this paper is to point out to a growing trend of interests of modern tourists for various forms of thematic tourism, as a response to the tendency of uniformity of consumers' lifestyle, which globalization has brought. Thanks to their central place in the tourism system and their expertise, tour operators play a key role in the creation of new programs, 'tailored' to the taste of modern tourists.

For that purpose, a number of theoretical assumptions and examples from practice have been analyzed and the method of understanding cause-and-effect relationships is used, in order to examine the role of tour operators in application of new thematic programs.

The need to emphasize the special customers' requirements regarding travel services cre-
\end{abstract}

\section{Introduction}

Modern trends in the global tourism market result from numerous factors on both sides - tourism demand and tourism supply. Increasing homogenization of needs and living styles of consumers, dynamic changes in the macro-environment of the tourism industry that require new organizational forms and conquering new markets, development of the computerized reservation network, deregulation of air transport, better positioning of consumers and market fragmentation have inevitably led to the creation of the global tourism market and new ates an additional problem to tour operators. It indicates the trend of individual trips, which requires a change in choice of markets and product differentiation.

The research findings suggest the conclusion that tour operators need to adapt their business strategies to new market conditions, using advantages of information technology in designing diverse thematic programs, which will enable tourists to perceive other local values and express their individuality looking for authentic experiences.

Key words: sophisticated consumers, flexible strategies, 'experience economy', tour operators, thematic tourism

structural developments in the international tourism market. Besides the aforementioned mega-trends, the efforts to preserve the environment and develop sustainable tourism, increased need for attractive and active vacation, too much free time, shorter, yet more frequent vacations, have all led to the evolution in the segmentation of tourism markets and affirmation of quality tourism.

The approach used so far to meet the needs of all tourists with a specific product or service has been replaced by a new one, which transforms the mass market into a large number of niches. Big heterogeneous market, dominated to a great extent by uni- 
form travel packages, has been divided into smaller, homogenous market segments of consumers with same or similar habits when it comes to selection of tourist travel. Opposite to mass tourism, there is an increased trend of thematic tourist activities that enable tourists to verify their own identity, promote their living styles and personal inclinations. There are various forms of thematic tourism and it is practically impossible to classify them fully, as the tourist demand often consists of a large number of mutually inter-related incentives. To that end, various characteristics are used as a basis for classification, which are important for the specific observation, research or analysis in the specific moment in time (Radović, 2010).

Thus, as life becomes more homogenous, the need to strengthen values of diversity increases, together with individuality. In tourism, this results in a paradox that homogenity and specialization result in the need to emphasize uniqueness in the demands of the travel service consumers. According to Hawkins (2006), there is a paradox of globalization and localization, which will require reorganization of the main players in the tourism market. To that end, the trend of individual travel inevitably leads to the need to restructure the market of tour operators with regard to market selection and product differentiation.

\section{Thematic tourism strategies}

Numerous destinations use thematic tourism to develop new tourist products, focusing on various segments of consumers, in order to expand visitor experience. Some of them belong to the already well-developed tourist destinations, while for others this development of thematic itineraries represents a predominant, sometimes even the only way to develop tourism. This usually applies to the developing destinations that have di- verse tourist resources, as well as numerous limitations, such as underdeveloped transportation infrastructure and utilities, lack of accommodation facilities, limited marketing knowledge and skilled workers. To that end, it is necessary to define strategies that will enable valorization of specific forms of tourism, and this involves the following stages:

- Critical analysis of the current state of thematic tourism in the country/ region

- Identification of potential thematic tourist products/services

- Definition of development strategy for thematic forms of tourism in the country/ region

- Implementation of the strategies defined in this way.

Analysis of the current situation is usually a critical one, having in mind that the need for upgrading tourist product is generally the result of an obvious downturn in business operations in a specific period of time. Quality of thematic tourism cannot be observed separately, but as an integral part of the overall destination development. Thus, its development follows, to a greater or lesser extent, the development of tourism in the region, irrespective of whether it is mass or thematic tourism. In that respect, life cycle of a destination, from entry into the market, to the period in which it is still economically justified to keep it in the production program (Popesku, 2011), characterizes life cycle of the thematic product. The concept of development of thematic forms of tourism provides for slower, in the long run more sustainable development, controlled by the local authorities. In this way, through continuous monitoring of tourist destination development, it is possible to ensure the transition from one stage in the living cycle of the destination to the next one. Introduction of specialized, thematic forms of tourism builds consumer loyalty and encourages them to return to the destination. It is only specialized tourist offer that ensures excellent service, leadership in the market and 
destination competitiveness (Kesar, 2013). One should have in mind that thematic route is understood as tourist destination in marketing terms only, although it exceeds the classical model of a tourist destination and has a much wider coverage. Thus, there are well known thematic paths of wine, pilgrimage tours, educational tourism, which are usually related to the underdeveloped destinations that are unable to implement this concept on their own and opt for various forms of partnerships and fit this offer into the integrated product.

The very identification of potential resources for development of thematic forms of tourism does not involve only the analysis of natural, material and human values, but an in-depth analysis of demographic characteristics and psychological profiles of the potential target markets, whose motive is to experience something new during the vacation. If we apply this to wine tours, Brown (2010) denotes that development of an effective strategy of wine tourism involves understanding demographics and consumer behavior from the aspect of their habits and propensity to buy.

Results of such an analysis are of key importance for the definition of more effective strategies for the development of thematic tourism, definition of market segments and marketing techniques for their implementation. Besides, they give a solution on how to strategically and economically position specific forms of thematic tourism in a specific destination in a way to promote regional thematic tourism. Getz (2005) stated that if the results show that wine is part of consumers' lifestyle, there is likely a strong predisposition for pleasure travel to wine regions - or at least to include wine in general-purpose travel.

However, having in mind the overall product complexity, it is hard to define a unique development strategy. Every destination, with its team of professionals in its managing companies, creates its own com- petitive strategy, based on the available resources and the possibilities for representation in the foreign markets.

Implementation of strategic solutions adopted in this way in practice is not easy at all. It involves use of adequate marketing tools, depending on the nature of resources, their quality and quantity, ability to integrate them in the tourist destination, and the provision of adequate distribution channels that will bring them to the consumers in an effective and efficient manner.

\section{Theoretical approach}

The issue of thematic tourism development and selection of adequate strategies and marketing solutions was tackled by numerous authors. Although different authors use different terms for this specific form of tourism in theory in practice: selective form of tourism, special interest tourism, niche tourism, alternative tourism, etc., (Rabotić, 2012), views of most of the authors can be combined into one definition - that this is the type of travel primarily engaged in order to fulfill a special interest and enjoy it, and this can be a hobby, physical activity, interest in a specific topic or a specific type of destination. It can refer to the forms of tourism focusing on activities or creation of environments that are attractive to specific market niches, i.e. a smaller number of tourists (Novelli, 2005). It can also refer to new locations, authentic products and experiences (Hall and Weiler, 1992). This could involve various forms of tourism, such as culture tourism that Douglas and Derrett (2001) refer to as a type of cultural impression that emphasizes the cultural, heritage or artistic aspects of destination or experiences and activities for the tourist. In other words, as MacCannell (1976) notes, opposite to mass tourism, cultural tourists look for 'authenticity' in their travel experience. The essence of the notion of thematic tourism is best 
described in the highly focused explanation by Drake, NTA's ${ }^{1}$ special interest guru, who says: "The special interest traveler doesn't travel to a destination, he travels to satisfy a special interest".

In order to satisfy their special interests, search for new experiences becomes a predominant consumer trend. Pine II \& Gilmore (in Hawkins and Nikolova, 2005) call this focusing on experience in tourism industry the 'experience economy', which adds real value to consumer experience. Speaking about the phenomenon of 'experience' in tourism, Hawkins starts from the 'experience', as the key innovation in the today's tourism business, through the 'visitor experience' all the way to 'promised experience.' By promising quality through the destination brand, thus easing the ability of the consumer to experience what was promised and see the quality for himself, management creates a 'visitor experience value chain' (Hawkins and Nikolova, 2005). The more educated the management team and the better equipped with marketing tools, the higher is the probability that the visitor experience value chain' will be more consistent. In its creation, tour operators play an important role, as they are travel package organizers, so they continuously monitor and are well informed about the needs and wishes of contemporary tourists (Đurašević, 2008*).

However, one should have in mind that introduction of the thematic tourism concept does not involve simultaneous creation of some new form of tourism, but it rather involves implementation of the new concept of tourist destination development, oriented towards the requirements of the demand side and its specific needs, while being based on sustainable development and market research. Such a model may generate greater income for all stakeholders in the market, employ more local labor force and

NTA is the leading association for professionals serving travelers to, from and within North America founded in 1951. significantly affect the development of family-based entrepreneurship (Kesar, 2007). Research related to this topic, undertaken by Acorn Consulting, argued that niche market tourists are not necessarily high spenders (although many are), thus, the development of niche market tourism does not necessarily have to increase the average tourist consumption (Caribbean Tourism Organisation, 2008). However, niche markets help in product diversification, minimizing the effects of seasonality, and reducing pressure on 'honey pot' areas by distributing tourists to lesser-visited places.

Numerous researches have dealt with the issue of the need to protect the touristic sites from excessive tourist visits and the need to manage the 'carrying capacity', as a ratio between the use and protection of a specific site. The city of Bruges is pre-eminent in Belgium's tourism industry and represents one of the best-protected cities in Northern Europe. As a part of the integrated tourism development plan, a traffic control plan was implemented in 1992, which improved the quality of tourist product and at the same time provided for balance between tourism and needs of the local population (Boniface and Cooper, 2005).

There are numerous ways that tour operators, the suppliers in the supply chain, and destinations themselves can earn from the resources of the region and wishes of the visitors to experience something exciting during their travel and to learn something new. Tour operators play an important role in designing such programs, their promotion and distribution to the targeted segments of the tourism demand - both, the big ones that expand their service portfolio by establishing specialized tour operators, as well as numerous operators of special interest tours, responsible for special travel themes and/or special destinations. 


\section{Thematic tourism product development}

Market transformation from the mass tourism market to the narrowly defined market segments that look for various forms of thematic tourism was also affected by the fact that tourists first decide on the motive of their travel, and only then they select the destination. Thus, if hiking or golf provide for the desired way of social and individual identification, the market should tend to find the destinations and resorts with golf fields or hiking sites (Jovanović, 2013).

This trend results from the change in the value system and the needs of the modern tourists, where their need for knowledge and new activities are continuously growing. From the aspect of strengthening the readiness of the tourist to use his free time for active vacation, tourist demand is no longer seeking 'value for money' only, but 'value for time' as well, and increasingly 'value for effort', too (Kesar, 2013). Characteristics of contemporary tourism development are changing, and thematic vacations and specific forms of tourism are becoming predominant direction of development (Poon, 1993).

At the same time, actors of the tourist supply side recognize the advantages of specialization. Specific touristic products represent partial products of an integrated touristic product, thus, the strategy of thematic tourism is based on marketing of those touristic products, activities and experiences, developed for specific market segments. Although special interest products are usually of a seasonal character, if the destination has high potential resources, it is possible to organize this form of tourism throughout the year, especially because its promotion usually does not entail large financial investment.

Every tourist planning a travel likes to know what is specific to see and what are the activities planned in a destination. This knowledge usually helps him select a spe- cific destination. For that reason, in order to strengthen thematic tourism and to make it more popular, it is necessary to encourage development of destination management companies (DMC), which usually define and develop different product segments. In support of the development of these programs, there are local or regional associations established.

In such conditions, a strong weapon in the organization of information regarding tourist attractions that can be seen and 'experienced' through thematic programs in a specific destination, as well as the way to present them to the visitors, is the so-called itinerary development, which is ultimately presented as the itinerary program. Travel organizers and all other actors in the distribution chain use itinerary programs in their various sales concepts. This is a process that is in tourism known as 'tourism product development' (Tabata, 2009). According to him, this process integrates: identification of natural and cultural resources that are unique to a region; integration and coordination of efforts of the private, public and NGO sectors in the protection and presentation of identified resources; as well as the development and marketing of the new product. Program designed in this way, which focuses on the whole, through integrated themes, creates a brand image for a destination, which makes it different from thousands of other competing destinations. In this way, numerous tourist destinations use thematic tourism to develop a new tourist product, strengthen destination brand and expand visitor experience.

Thus, the researchers Brown and Smith (2010) used the experience of wine cellars in North Carolina to demonstrate the potential power of promoting wine tourism in attracting consumers to this region. There are common examples of festivals, various competitions and cultural events being quoted as successful strategies in the communication of regional brand image (Getz, 2005). In re- 
cent times, the very popular photographic holidays have helped develop numerous regions, made them well known and emphasized the need for their increased protection. Some of the famous photo tours are: photo cruises of Antarctica, New Zealand flying safaris and African wildlife and landscape photo safaris (Van Os, 2003).

\section{Tour operators' new business models}

Observing the increasing requests by the consumers for individualized travel, abandonment of traditional forms of mass tourism holiday - the 3S (sun, sea, send), tour operators are changing their business strategy and opt for greater product diversification and selection of market segments that they can service in a quality way in the long run. The economy of scale strategy, which is obviously the road to profits, is becoming less important to them and is replaced by the high margin strategy and reduced scope of operations (Buhalis and Costa, 2006). Increased use of information technologies in the tourism sector is guided by the increase in size and complexity of the tourism demand, sophisticated touristic products and services developed for small market segments (Cooper and Buhalis, 1998). However, tourism expansion is not followed by change in the demand side only, but on the supply side, as well, resulting in the opening of new, less developed and diversified markets, which creates a richer offer and increased competition.

While in the earlier stage of tourism the tour operators were the ones to discover destinations and direct the demand towards receptive countries, now the situation has changed and the tour operators adapt to the new consumers' desires and search for new experiences. Thus, the tour operators have affected the development of demand for completely new forms of tourism, such as the- matic travel, adventure programs, cultural tours, ecotourism, cruises and many others. Organizing such packages, the tour operators have created new segments of touristic demand, such as the youth segment, looking for vacation full of excitement, sports and adventures, then the older-age tourists, who wish to spend the winter in warmer regions, under the cost that is lower than the one at home, conference market (MICE) and business tourism, that companies are increasingly opting for to train their staff, but also to help them socialize and strengthen the feeling of belonging to the company.

Characteristics and structure of demand are continuously changing, thus, travel organizers follow the trends preferred by the consumers, and over time, with the creation of an adequate offer, they affect the characteristics of that demand, as well as its structure. Even the individual tourists, who organize their trips on their own, look into market possibilities and accept trends based on tour operators' offers, who use various marketing activities to bring their offer closer to the public. In this way, tour operators are becoming the creators of new, touristically experienced population.

In order to renew their operations, tour operators are looking for new strategies, selection of new products, packaging and 'unpackaging' of its components, market segmentation, product diversification, improvement of brand conditions, they apply useful value strategies - 'value for money' and 'value added' (Đurašević, 2008*). In order to increase competitiveness, tour operators use multi-channel distribution strategy that offers search and booking at the same time, which is a huge advantage for the consumers, and enables their principals to deliver products and services in various forms and combinations, thus maximizing their yield. From the point of view of consumers, Consumer Centric Marketing (CCM) represents a good model for establishment of innovative organization, which realistically 
has its shortcomings, especially with regard to expressed diversity dynamics preferred recently by 'fashionable' travelers.

Among these strategies, dynamic packaging (DP) that gives added value to special interest tours is considered one of the most effective. This is especially true having in mind that DP tour operators, unlike classical ones, do not suffer from the risk of being forced to sell the purchased bed quota in the hotel or airplane seats quota; they are consumer oriented, and not focused on their goods. Offering flexibility, ease and pleasure of creating 'customized' vacation in real time, without unnecessary internet searches in order to develop an adequate tailor made tour, 'DP' is recognized as 'cure' not only for travel customization, but for profit margin and brand erosion (Đurašević, 2007).

In order to attract as many tourists as possible, tour operators change business models, thus marginalizing destination, putting an emphasis on the use of vacation through specific activity. In this way, they give themselves an opportunity to abandon the destination if they feel for any reason that it is not favorable for them and they always have a reserve one to replace it with, because they specialize in specific activities, not destinations. This is one of the tactics that is harmful for destination development, but it builds a special thematic segments, such as the well-known adventure programs 'jet boating', 'bungee' and rafting fast waters in New Zealand, the US or Montenegro.

However, thematic tourism can act as a strong impetus for development. A good example is Scotland, the cradle of golf, which has over 500 golf fields and has built a powerful brand image not only among golf fans, but the Golf Open in St. Andrews became the brand of Scotland, yielding GBP 100 million each year, $70 \%$ of which comes from British tourists. These are wealthier clients, compared to other groups of tourists. It is considered that one golfer brings three times higher revenues than a foreign tourist visiting Great Britain (Page, 2005).

Organization of this type of travel is usually performed by smaller tour operators, who are often specialized in specific activities, such as the famous British tour operator for religious tourism Pilgrim Holidays. Still, one should have in mind that the largest part of the cake in this segment belongs to big tour operators who, for the sake of preserving their power through the economy of scale, introduce flexible strategies in their operations and organize numerous thematic programs all over the world. Their advantage is the strong vertical and horizontal structure and their openness to numerous destinations and network of suppliers. Thus, the motto of the big TUI in the Specialist \& Activity sector is as follows: 'If you can dream it, we can take you there.' This sector comprises over 100 global travel businesses to fulfill the holiday and travel needs of customers with a wide range of interests and passions (TUI Travel PLC, 2013).

Contemporary development of tourism demand shows that there are two opposing trends in existence: one is increased demand for travel packages, and the other is increase in personal autonomy in the selection of travel. In relation to that, it should be mentioned that the occurrence of low-cost companies that fly to numerous destinations today is becoming a threat to tour operators business and draws away one part of special interest travelers. The reason is that they use direct distribution channel via Internet, thus eliminating the classical tour operator and the travel agency with regard to transport. One should have in mind that modern 'nomads' usually do not care for the destination, but for a good vacation, no matter where it will take place (Đurašević, 2008). This fact is compatible with the view expressed in the beginning of this text - that special interest traveler does not select a destination because of the destination itself, but because of the satisfaction of his special interest. 


\section{Conclusion}

The existing tendency of gradual shift to uniform living styles that comes with globalization, leads to the abolishment of geographical and cultural barriers, and creation of space for total product distribution. Together with the significant increase in the number of 'organized' tourists, there is an increasing need for independence, autonomy, freedom of movement and freedom of choice. Search for new experiences becomes a predominant consumer trend. This trend is fully supported by the continuous IT development.

As the mass tourism gradually leaves the development initiative to the special forms of tourism, the tour operators, as the most powerful traditional sellers in tourism turn to new strategies in the selection of their product spectrum, packaging and separate sale of its components, market segmentation, product diversification. With the 'unpackaging' and changes in consumer behavior, multi-channel management supports their profitable growth. Travellers are increasingly attracted by other strategies, such as 'micromarketing' or 'niche' marketing.

On this path, it is necessary to establish cooperation and networks with numerous suppliers in the destination, as well as with the responsible organizations engaged in destination management. The reason being that the process and organizational innovations are what is most lacking (e.g. The Lisbon and EU 2020 strategies) (EC, 2009 and 2010). Continuous changes on the demand side result in suffering of service providers. This requires an innovative approach in the creation of a wide range of niche tourism forms that will be based on quality, because tourists are searching for sustainable and authentic models of holidays instead of mass tourism.

For that reason, among numerous strategies used by tour operators, the future belongs to the contemporary model of knowledge-based dynamic packaging that will be able to provide added value to special interest tours. Possibilities for implementation of dynamic interaction of information provided by numerous suppliers with the wishes and needs of the niche travelers will represent a successful combination for the tour operators, as well as consumers.

It is expected that CCM will remain a standard among consumers in the years to come. Consumer will be given a central place and all the due respect, with the organization that will result in real savings and profit, using the ICT. Success will be achieved by those managerial teams that manage to follow the pace of change and use that change in collecting information, their innovative organization and distribution, all with the aim to improve the experiences of tourists who are eager to smart trip offers of active tourism.

\section{References}

Boniface, B. and Cooper, C. (2005) Worldwide Destinations Casebook - The geography of travel and tourism, Elsevier ButterworthHeinemann, Oxford.

Brown, A.C. and Smith, F.R. (2010) Wine Tourism: A serious Leisure Approach, Journal of Service Science, 3(1), p. 29-33.

Brown, G. and Getz, D. (2005) Linking wine preferences to the choice of wine tourism destinations, Journal of Travel Research, 43, p. 266-276.

Buhalis, D. and Costa, C. (2006) Tourism Business Frontiers-consumers, products and industry, Elsevier Butterworth-Heinemann, Burlington, MA, USA.

Cooper, C. and Buhalis, D. (1998) The future of tourism, in Cooper, C., Fletcher, J., Gilbert, D., Shepherd, R. and Wanhill, S. (eds.), Second ed, Tourism: Principles and Practice, Addison Wesley Longman, London.

Caribbean Tourism Organisation, (2008) Developing a Niche Tourism Market Database for the Caribbean, Acorn Consulting Partnership Ltd. 
Douglas, N., Douglas, N. and Derrett, R. (2001) Special interest tourism: Context and cases, Milton, Qld: John Wiley\&Sons, Australia, Ltd.

Đurašević, S. (1995) The Possible Development of Tour Operations for Montenegro, M.Sc. in Tourism Marketing, University of Surrey, Guildford, UK.

Đurašević, S. (2008) Turistička putovanja-savremeni koncepti prodaje, CID, Podgorica, Crna Gora.

Đurašević, S. (2008*) Koncept lanca vrijednosti u turizmu, Hotel link, tom 12, Viša Hotelijerska škola, Beograd, Srbija.

Đurašević, S. (2007) Uticaj informacionih tehnologija na posrednike u turizmu Hotel link", tom 9-10, Viša Hotelijerska škola, Beograd, Srbija.

European Commission (2009) The Future "Eu 2020" Strategy, Provisional, COM 647/3, Brussels.

European Commission (2010) Lisabon Strategy, Working document, SEC 114 final, Brussels.

Getz, D. (2005) Event Management and Event Tourism, 2nd edition, Cognizant Communicion Corporation, New York.

Hall, C. M. and Weiler, B. (1992) Introduction. What's special about special interest tourism, in Weiler, B. and Hall, C. M. (Eds.), Special interest tourism, p. 1-14, New York, Wiley.

Hamović, V., Subić, J. and Bošković, D. (2010) Special Interest Tourism with Exceptional Emphasis on Istrian Region and Kolubara District, Petroleum-Gas University of Ploiesti, Bulletin Vol. LXII, No. 2, str. 57-66.

Hawkins, D. and Nikolova, M. (2005) Knowledge Applications for Competitive Destinations, WTO Education Council General Assembly Conference, Dakar, Senegal.

Hawkins, D. (2006) Sustaining Tourism in Times of Uncertainty, Faculty of Tourism and Hospitality Management, Singidunum University, Belgrade, Serbia.

Jovanović, V. (2013) Tematski turizam, skripta, Univerzitet Singidunum, Fakultet za turistički i hotelijerski menadžment, Beograd.
Kesar, O. (2013) Uvod u specifične oblike turiz$m a$, Ekonomski fakultet, nastavni tekst iz kolegija „Specifični oblici turizma”, Zagreb.

Kesar, O. (2007) Specifični oblici turizma kao nositelji održivog razvoja destinacije, $\mathrm{u}$ Bartoluci, M. i Čavlek, N., (Ed.), Turizam i sport - razvojni aspekti, Školska knjiga, Zagreb, str. 50-57.

MacCannell, D. (1976) The tourist: A new theory of the leasure class, NY: Schocken Books, New York.

Novelli, M. (2005) Niche tourism: Contemporary issues, trends and cases, Burlington, Elsevier, MA., USA.

Page, S. (2005) Tourism Management, managing for change, Elsevier Butterworth-Heinemann, Burlington, MA, USA.

Poon, A. (1993) Tourism, Tehnology and Competitive Srategies, $\mathrm{CAB}$ International, $\mathrm{Ox}$ ford.

Popesku, J. (2011) Menadžment turističke destinacije, Univerzitet Singidunum, Fakultet za turistički i hotelijerski menadžment, Beograd.

Rabotić, B. (2012) Selektivni oblici turizma, Visoka turističkaškola, Beograd.

Radović, M. (2010) Turistička geografija Crne Gore, Fakultet za turizam, hotelijerstvo i trgovinu, Bar i Fakultet za turizam i hotelierstvo, Crna Gora.

Šećibović, R., Mičić, M., Komlenović, Đ. i Đoković, E. (2005) Uvod u geografiju turizma sa osnovama prostornog planiranja, CID Ekonomski fakultet, Beograd.

Tabata, S. R. (2009) Thematic Itineraries: An Approach to tourism product development, Sea Grant Extension Service, University of Hawai at Manoa, USA.

Van Os Joseph (2003) Photo Safaris, Worldwide Photographic Tours brochure.

\section{Websites:}

www.tuitravelplc.com, Oct. 2013. 
